\title{
112 血栓症測定装置（GTT）内流れの解析
}

Numerical analysis on the flow in GTT tube

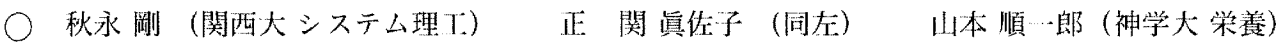

Takeshi AhINAGA, Kansai University, Yamate-cho 3-3-35, Suita

Masako SUGIHARA-SEKI, Kansai University, Yamate-cho 3-3-35, Suita

Junichiro YAMAMOTO, Kobe Gaknin University, Ikawadani-cho, Nishi-ku, Kolbe

\section{1 はじめに}

血栓の形成は，生理的にも病理的にも重要な意義をもって いる、血小板の機能を簡便な手法で正確に訃測することがで きれば臨休において極めて有用であるので，こ扎までその訃 測手法についていくつかの試みがなされてきた。その中で, Görög Thrombosis Test (GTT) チューブ (Fig. 1 参照) を 用いて血小板の凝集および溶解を測定する手法は，ずり(せ ん断）応力によって血小板を活性化させて凝集能を調べるも ので，全血そのままで棓測できるという特長をもつり。

本研究では，GTTチューブ内における血小板の凝集と溶 解の機序を明らかにするための第一歩として, GTTチュー ブ内の流机およびせん断応力分布を, 数値解析により調べた。

\section{2 方法}

Fig. 1 に示すようにGTTチューブは，脽錐形管と，中 に入っている，サイズの異なる 2 個の洞体球からなる。管 の内壁表面には，幅が狭く薄い板が挿入されており，そ扎が スペーサーの役割をして，管内壁と球との間に一定の隙間を 作っている. 血液を GTT チューブの上側から流すと, 球を 管壁の腺間では流扟が速く, 強いせん断志力が働いている と予想されるので，血小板は鼠初の腺間を通る間に活性化 され，2 個の球の間の領域で凝集を起こしやすくなる。そし て, 次の嚐間の近傍では次第に血小板が管壁に粘着と堆積を して流れを妨げ，時間の経過とともに血液は流れにくくなる 1). GTTチューブ下端から落下する血液の時間経過を計測 することで，このような血栓形成の度合いを測ることができ

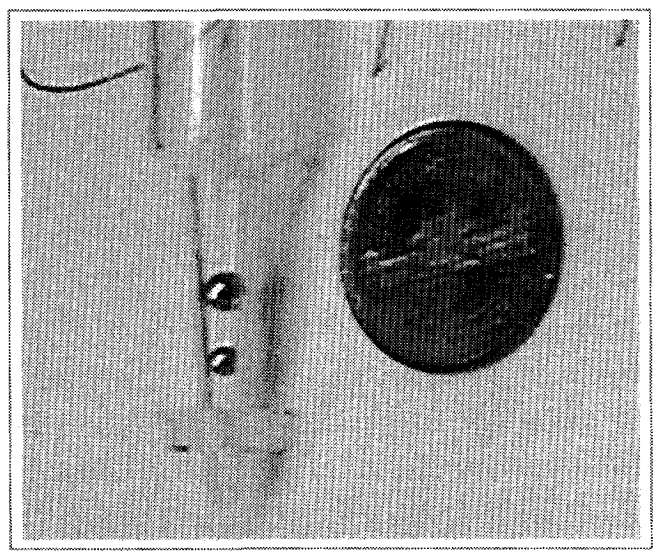

Fig. 1 GTT tube.

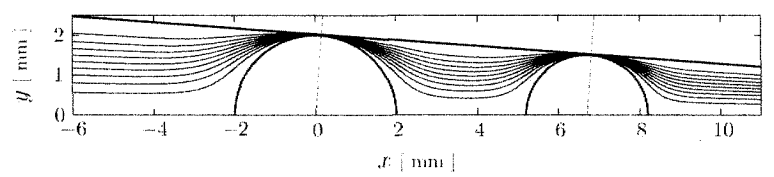

Fig. 2 Stream lines in the symmetric plane.

\section{ると考光られる。}

本研究では次のようなモデル化を行ってGTT チューブ内 の流机を流体力学的観点から解析する。まず，GTTチュー ブ内の 2 つ球の半径を $a_{1}, a_{2}\left(<a_{1}\right)$ とし, そ扎らは心 間距離 $L$ で, 円錐管の中心軸上に位置し, 管内壁と2つ0 球表面の距離 $d$ は等しいものとする，簡単のため，非压縮 性ニュートン流体の軸対称流孔を考える，また，遅い流孔を 想定し，慣性の影響は無視できるものとすると，流机場は， ストークスの流れ関数

$$
\mathcal{D}^{2}\left(\mathcal{D}^{2}(\psi)\right)=0
$$

により記述される。ここで，管軸方向を $x$ ，動径方向を $y$ と して, $\mathcal{D}^{2}=\partial^{2} / \partial y^{2}-1 / y \cdot \partial / \partial y+\partial^{2} / \partial x^{2}$ である. 境界条 件として，管壁面と球表面に滑りなし条件

$$
\frac{1}{y} \frac{\partial \psi}{\partial x}=-\frac{1}{y} \frac{\partial \psi}{\partial y}=0
$$

を課す．上流と下流の条件として，球がない場合の円錐管内 ストークス流れの縓密解 ${ }^{2)}$ をえる.

式 (1) を境界条件 (2)のもとに，スペクトル有限要素法を 用いて数嗔的に解く. $N^{e}$ 個の直線とは限らない辺を持つ四 角形を用いて計算領域を分割する。空の際, 管壁面と球表面 の間隙が小さい場所で流れ方向に要素が細かくかつ多くな るようにする，各各の要素内で $\left(N^{p}+1\right)^{2}$ 個の独立な双 $N^{p}$ 次関数を定義し，この関数展開によりをを近似しガレルキ ン射影を行えば，致開係数に対する線形代数方程式が得られ る。こ扎を数值的に解くことでもの近似解を得る。本稿で は $N^{e}=105, N^{p}=7$ とする。

\section{3 結果と考察}

球の半径が $a_{1}=2.0 \mathrm{~mm}, a_{2}=1.5 \mathrm{~mm}$, 球の中心間 距離が $L=6.7 \mathrm{~mm}$, 球表面と管壁の距離 $d$ が $20 \mu \mathrm{m}$ $\leq d \leq 50 \mu \mathrm{m}$ の場合を取り扱った.

解析結果の‥例として, $d=25 \mu \mathrm{m}$ の場合に見られる，対 称面内の流線を Fig. 2 に示した。この図では，上流側の大

日本機械学会 [No. 07-49] 第 20 回バイオエンジニアリング講演論文集（'08-1.25〜26 東京） 


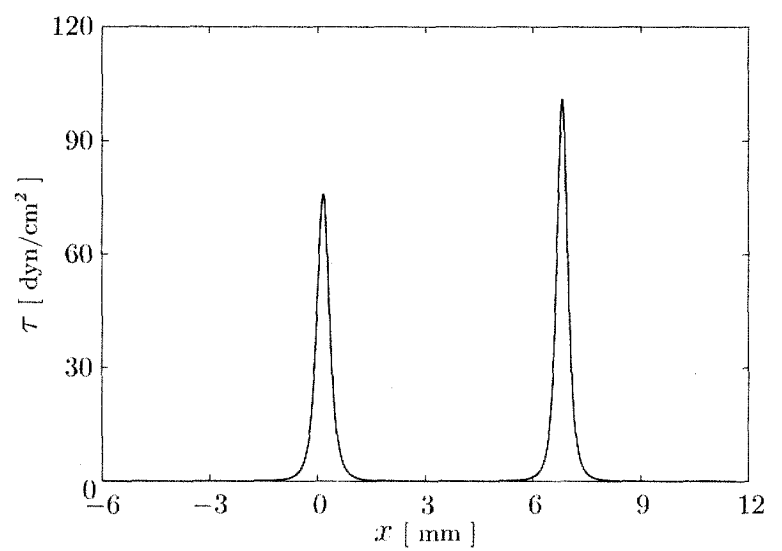

Fig. 3 Shear stress distribution on the tube wall. $d=$ $25 \mu \mathrm{m}, Q=0.01 \mathrm{~cm} 3 / \mathrm{s}, \mu=0.01 \mathrm{dyn} \cdot \mathrm{s} / \mathrm{cm}^{2}$.

きな球の中心を $x$ 軸の原点としている。このとき，流量を $Q=0.01 \mathrm{~cm}^{3} / \mathrm{s}$, 流体の粘性率を $\mu=0.01 \mathrm{dyn} \cdot \mathrm{s} / \mathrm{cm}^{2}$ と した場合について，管壁扮よび球表面に働くせん断応力分布 を，そ执ぞ机 Figs. 3，4亿描いた。管壁に㗢くせん断纫力 は，2 個の球に近付くと急激に大きな值となり，球と管壁の 隙間が最小となる筒所，すなわち球の中心 $x=0.6 .7 \mathrm{~mm}$ よりも少し下流で最大となる。上流の球近傍で最大值 75.9 $\mathrm{dyn} / \mathrm{cm}^{2}$, 下流の球近傍で $100.9 \mathrm{dyn} / \mathrm{cm}^{2}$ まで上昇するこ とが分かる. Fig. 4 は，球表面の点と球中心を結が線分が $x$ 軸に対してなす角 $\theta$ の関数として, 球表面に動くせん断 态力分布を表したものである，2個の球とも，球と管壁の隙

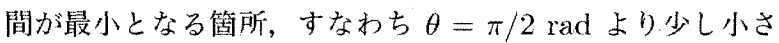
な角度 $\theta=0.476 \pi \mathrm{rad}$ でせん断応力熶大となる。最大值 は，上流と下流の球それぞれで， $76.5 \mathrm{dyn} / \mathrm{cm}^{2}$ および 102.0 $\mathrm{dyn} / \mathrm{cm}^{2}$ である。ここで，(1) 式は線形であるので, せん断 応力の大きさは，流量と粘性率に比例することに注意した い，流量や粘性率が変化すると，Figs. 3, 4 に示す分布は形 を保ったまま, その大きさが流量や粘性率に比例して変化 する。

次に, 流量 $Q$ が $0.01 \mathrm{~cm}^{3} / \mathrm{s}$, 流体の粘性率 $\mu=0.01$ $\mathrm{dyn} \cdot \mathrm{s} / \mathrm{cm}^{2}$ の場合に, 球表面に働くせん断応力の最大值が, 球と管壁の腺間 $d$ によってどのように変化するかを Fig. 5 に表した。 Figs. 3，4から分かるように，2 個の球と管壁の 妳間において，管壁に働くせん断忍力の最大值は球表面に働 くせん断闷力の最大值とほぼ等しい。また，この隙間の領域 において，流体に㗢くせん断忍力は，たかだか管壁および球 表面でのせん断応力の大きさと同程度かそ扎以下であると考 えられる。したがって，せん断応力による血小板の活性化を 考えた場合に，そのせん断応力の最小値を $50 \mathrm{dyn} / \mathrm{cm}^{2}$ とす 扎ば ${ }^{1)}$ ，設定した条件下では， $d<30 \mu \mathrm{m}$ が，上流の球と管 壁との陌間で血小板が活性化される必要条件となることが推 測される。

\section{4 おわりに}

GTT千ューブ内の流扎を，定常な軸对称ストータス流孔 と仮定して解析した。流線と，管壁および球表面に㗢くせん

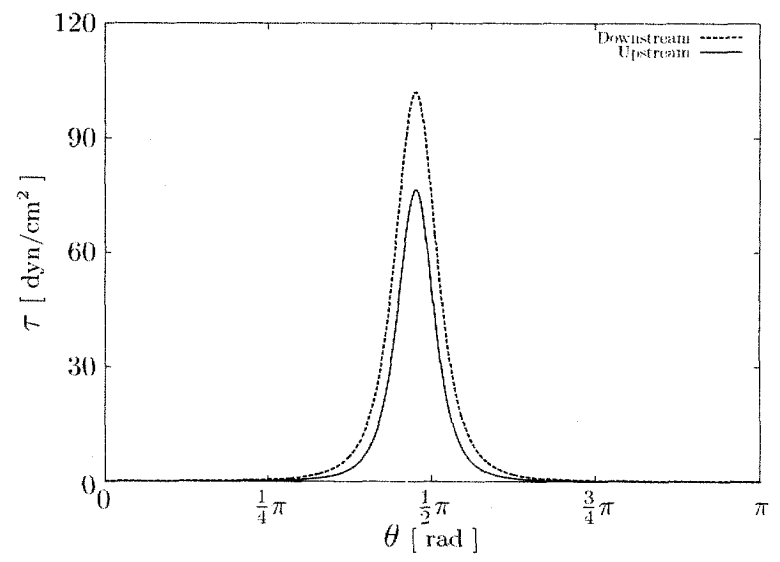

Fig. 4 Shear stress distribution on the surfaces of the spheres. $\quad d=25 \mu \mathrm{m}, Q=0.01 \mathrm{~cm}^{3} / \mathrm{s}, \quad \mu=0.01$ dyn $\cdot s / \mathrm{cm}^{2}$. The solid curve represents the values for the upstream sphere and the dashed curve for the downstream sphere.

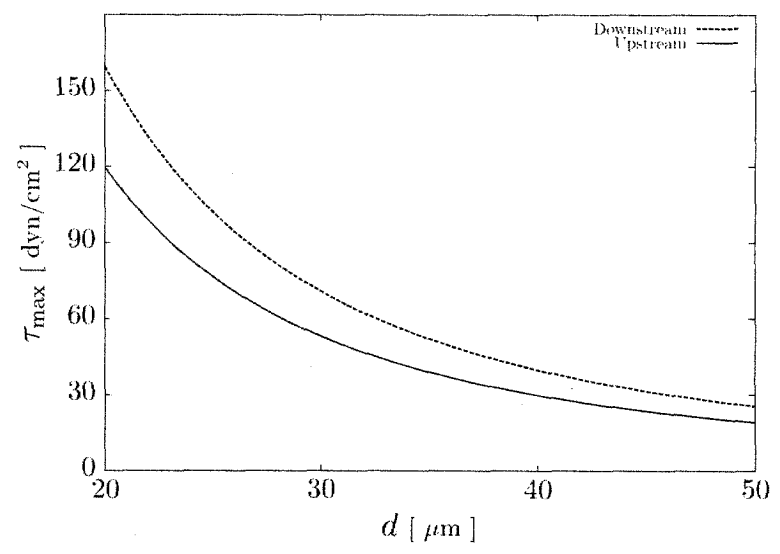

Fig. 5 The maximum values of the shear stress exerted on the upstream (solid curve) and the downstream spheres (dashed curve). $Q=0.01 \mathrm{~cm}^{3} / \mathrm{s}, \mu=0.01 \mathrm{dyn} \cdot \mathrm{s} / \mathrm{cm}^{2}$.

断応力分布について詳しく調べた．今後，GTTチューブ内 の血小板運動の解析を行い，血小板の凝集について調べる予 定である。

本研究の一部を科学研究費補助金基盤研究 (B) 16360090 によって行った.

\section{参考文献}

1) Yamamoto J., Yamashita T., Ikarugi H., Taka T., Hashimoto M., Ishii H., Watanabe S. and Kovacs I. B., "Görög Thrombosis Test: A global in vitro test of platelet function and thrombolysis" , Blood Coagulation and Fibrinolysis, 2003, 14, pp. 31-39.

2）日本流体力学会編「流体力学ハンドブック」，1998, p. 86 , 丸善. 